\title{
Optimization of Hydropower Plant Implementation with Hydrological Data for One Year: Movo Hydropower Plant Case
}

\author{
Hubert Kazadi Mabika, Anyume Kokole \\ Polytechnics Faculty, Kinshasa University \\ Kinshasa XI, Kinshasa, Democratic Republic of Congo \\ polytechnique@unikin.ac.cd
}

\begin{abstract}
Usually one needs to achieve Hydropower Power Feasibility Study, hydrologic data for at least 15 years back. But for most of the developing country like DRC, those data are not available and most of new mining companies cannot wait more than 2 years to develop their project in which hydro energy is a key line to make their project profitable. With one year hydrologic sampling data and following the course of the river with the tools like GOOGLE EARTH, GLOBAL MAPPER, WORLD CLIMAT, make it possible to detect large valleys along the river course in which, with the help of some earth dams and some set of spillways and channels, for storage during raining season and harvesting during dry season, will increase hydropower availability and boost mining profitability. Application is made for MOVO HYDRO POWER PLANT and TSHIBWE DIAMOND MINE in Western KASAI PROVINCE in DRC.
\end{abstract}

Keywords: New Software of Optimization of Hydropower Plants Implementation.

\section{Introduction}

Given the absence of hydrologic data, but in the presence of not too far WORLD CLIMAT station of KANANGA, a hydrometric sampling station has been settled on the Movo river in 2013, for one year, in order to implement an hydropower plant onto a 49m waterfall, necessary to supply cheap energy to Tshibwe diamond mine. Using Google Earth Pro, Autodesk civil 3D software make it feasible to organize the Movo river feeding basin, in order to sort out hydropower energy shortage during dry season.

\subsection{Specific Requirements of Movo Hydro Power Plant Related to Tshibwe Diamond Mine Needs}

A power demand of $1600 \mathrm{KW}$ requires a flow of $3.84 \mathrm{~m} 3 / \mathrm{s}$ in the MOVO River(49m water fall).

Surveys from September 2013 to March 2014 show that an average flow value of more than $3.84 \mathrm{~m} 3 / \mathrm{s}$ is found in the MOVO River, only from November to the end of April, for only 6 months.

The current developments of the basins at the MOVO plant have the following characteristics:

Table 1: Feeding Basins at MOVO Hydropower Plant.

\begin{tabular}{|l|c|c|}
\hline \multicolumn{1}{|c|}{ DESIGNATION } & \multicolumn{2}{|c|}{ BASINS DONE AT THE CENTRAL MOVO } \\
\cline { 2 - 3 } & Initial Basin (2014) & $\begin{array}{c}\text { Extended Basin Accumulation Dam } \\
(\mathbf{2 0 1 5})\end{array}$ \\
\hline Surface & $10000 \mathrm{~m}^{2}$ & $158984 \mathrm{~m}^{2}$ \\
\hline Gross capacity & $58800 \mathrm{~m}^{3}$ & $635936 \mathrm{~m}^{3}$ \\
\hline $\begin{array}{l}\text { Useful capacity (60 à } \\
70 \%)\end{array}$ & $35280 \mathrm{~m}^{3}$ & $455155 \mathrm{~m}^{3}$ \\
\hline
\end{tabular}

As the daily water volume requirement that the MOVO River must provide to the Central to deliver constantly 1600 KW is: $3.84 \mathrm{~m} 3 / \mathrm{s} \times 3600 \mathrm{~s} \times 24 \mathrm{~h}=331776 \mathrm{~m} 3$.

The last accumulation dam basin, allows only a 1.34 day reserve of flow required for the provision of $1600 \mathrm{KW}$ constant at Tshibwe Plant, after the cessation of rains. 


\section{Topography}

\subsection{General Topographical Documents Used}

The detailed cartographic documents dating back to colonial times have not been reprinted anymore, it is difficult to obtain them, but as a precious relic we have been able to save an eve map of the "TERRITORY OF BAKWANGA, SCALE 1/200 000, YEAR 1958" of the GEOGRAPHICAL INSTITUTE OF THE BELGIAN CONGO.

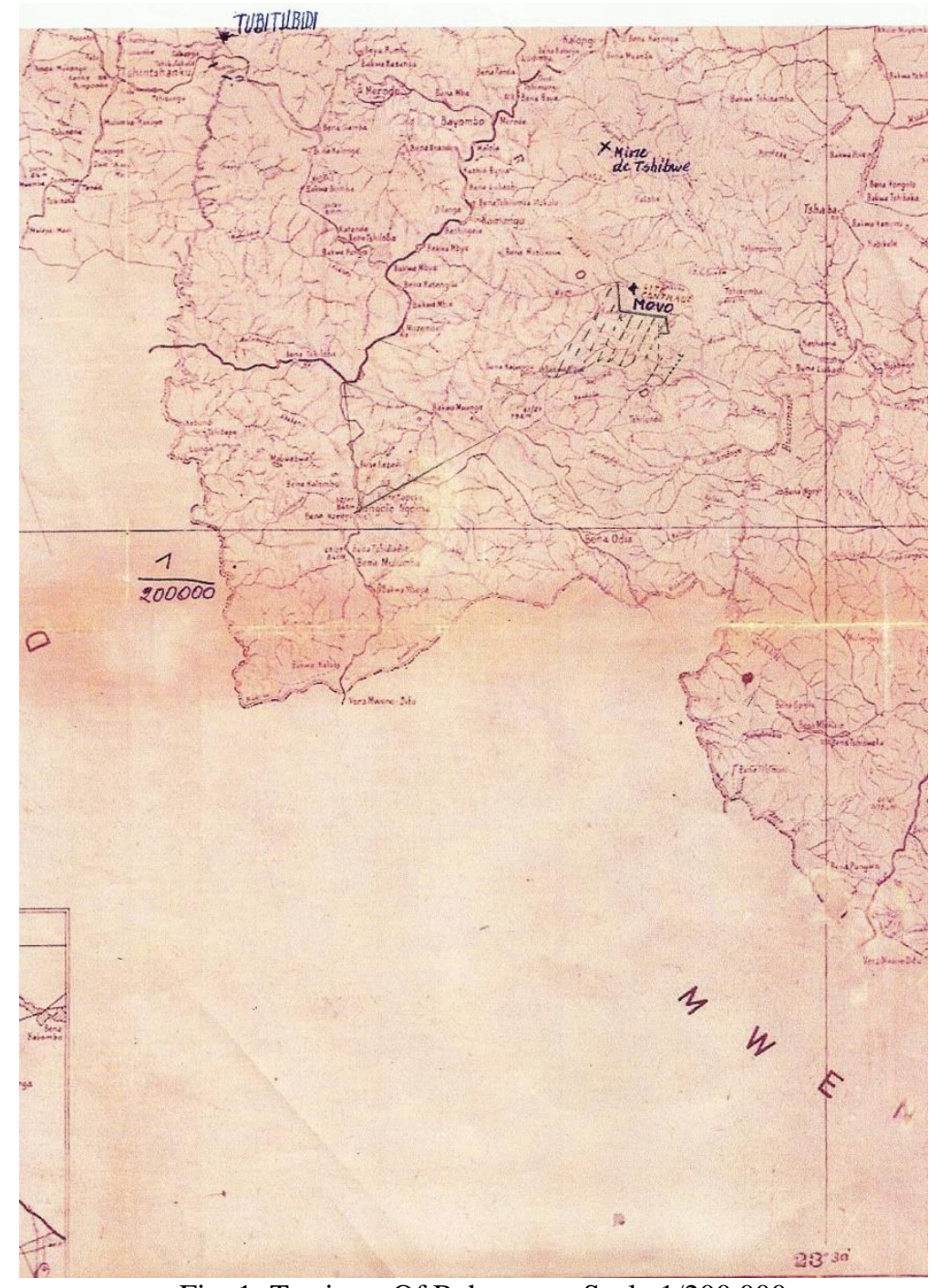

Fig. 1: Territory Of Bakwanga, Scale 1/200 000.

It is observed on this map that the catchment area of the MOVO before the Central consists of two almost vertical branches whose junction point is located $6 \mathrm{~km}$ upstream of the Centrale. The planning of this watershed gives an area of $76,32 \mathrm{Km}^{2}$.

The eastern flank of this watershed is bounded by the crest line of the road that passes through the Central, moving from southwestern to northeastern.

$5 \mathrm{~km}$ southwest of the Centrale, the road crosses another road that moves from WEST to EAST on another ridge line to cross the Mbuji-Mayi river vertically. It is thus the depression between these 2 lines of ridges, in the South of the Central on the right bank of the MOVO river which flows from West to East that appears the possibility to organize a large reservoir of water accumulation of tens of millions of cubic meters and also add the area of this depression to the MOVO watershed. In addition, the largest tributary of the MOVO on the right after the Centrale is located in this zone of the 
depression, so it is possible to organize hydraulic works, if the topography allows it to bring it back upstream the power station to get to all time of the year the addition of its flow to that coming from the initial watershed of the MOVO.

To overcome this painstaking task, we had to use GLOBAL MAPPER, GOOGLE EARTH PRO and AUTODESK CIVIL 3D software to scan this target area deeply.

\subsection{Topography Survey}

It is first of all to find, downstream of the depression zone towards the MOVO river, a crest line allowing on the one hand to drain through a channel the right tributary of the MOVO river towards the INITIAL BASIN of the MOVO power plant and on the other hand to raise a dike along this ridge, minimizing the excavation work and moving materials necessary for these achievements.

The dike will transform the depression zone into a storage tank of several tens of millions of cubic meters of water to cover the long periods of water shortage in the MOVO River.

The multiple iterations, with the software GLOBAL MAPPER, GOOGLE EARTH PRO and AUTODESK CIVIL 3D finally give the series of 22 plans (to consult in the appendices) to allow us to reach the objectives mentioned above.

\subsection{Description of the Site's Topography}

The zone of depression limited to the right bank of the MOVO river in the vicinity of the Central, by the tributary drainage channel and the dike, is reported on the map of "TERRITOIRE DE BAKWANGA, SCALE 1/200 000, YEAR 1958 "focusing on the encompassing space:

- The Mbuji-Mayi River

- The MOVO River and the site of its Central

- The Tshibwe Mine

- The Lubi river and its TUBITUBIDI site.

As can be seen on this map.

The planimetrical assessment of this zone gives $14 \mathrm{Km}^{2}$ additional to $76,32 \mathrm{Km}^{2}$ of the initial watershed of the MOVO before the site of the power station.

The coordinates of the 22 previous plans obtained by GLOBAL MAPPER and GOOGLE EARTH PRO will be brought back to our usual Congolese UTM / WSG 1984 topographic system and the altitudes will have to be attached to the general Congo (NGC) upgrade.

The markings at the initial basin of the power station and the accumulation basin with valve in adjustable drilled orifice and spillway will be set up to control the new configuration.

For a bottom dike of the depression zone having a trapezoidal section of:

- $7.5 \mathrm{~m}$ upper base,

- 9,0 m lower base,

- 4, 7 m high.

The cross section is $38,775 \mathrm{~m}^{2}$.

The footage, from successive lengths from 0 to $6192 \mathrm{~m}$ the final length of the New Channel and Dyke Trace, from PLANS 18 and 19, gives:

Total: $3242 \mathrm{~m}$ built length of dike.

That is to say a cubage of $3242 \mathrm{~m} \mathrm{x} 38,775 \mathrm{~m}^{2}=125708 \mathrm{~m} 3$ for the erection of this bottom dyke of the zone of depression.

The PLAN N ${ }^{\circ} 1$ for the New Route Var 2, shows that the excavated volume of $255150 \mathrm{~m}^{3}$ will be sufficient to cover the cubage of this dike and the embankment of this route $=125708 \mathrm{~m}^{3}+33270 \mathrm{~m}^{3}=163979 \mathrm{~m}^{3}<255,150 \mathrm{~m}^{3}$.

The cumulative width of the erected course of the dike of $3242 \mathrm{~m}$ on $6192 \mathrm{~m}$ of the route, represents $52.3 \%$ of the course, the planimetrical surface of the zone of depression of $14 \mathrm{Km}^{2}=1400000 \mathrm{~m}^{2}$, the cumulative height of water between the height of $665 \mathrm{~m}$ for the project and the leveling of the dike is $699.7 \mathrm{~m}$; therefore, a cumulative difference in water height of $4.7 \mathrm{~m}$; give: $0,523 \times 14000000 \times 4.7=34451486 \mathrm{~m} 3$ as the minimum cumulative volume of water in the zone of depression.

The section of hydrology which will follow will be able to determine the volume of water that the physical particularities of the basin of MOVO thus refitted will be able to bring in this zone of depression. 


\section{Hydrology}

\subsection{Summary of the Main Results}

- MOVO watershed upstream from the site of the MOVO power plant (see map of the aforementioned Bakwanga territory around MOVO) extends in 2 branches that meet perpendicularly $6 \mathrm{~km}$ upstream from the site of the power station :

I. First limb (S-N orientation)

- On the surface: $46,72 \mathrm{Km}^{2}$

- Length: $11 \mathrm{Km}$

- Width: 4, $25 \mathrm{Km}$

- Altitude upstream South: $684 \mathrm{~m}$

II. Second branch (W-E Orientation)

- On the surface: $29,6 \mathrm{Km}^{2}$

- Length: $10 \mathrm{Km}$ to the site of the hydropower plant

- Width: 2, $96 \mathrm{Km}$

- Altitude upstream West: $670 \mathrm{~m}$

- The specific MOVO flows estimated from the surveys from September 2013 to March 2014 (by supplementing the missing data by statistical extension according to the rainfall of Tshibwe and Kananga)

- Module (average annual flow):

$2.76 \mathrm{~m} 3 / \mathrm{sec}$ (36 liters / sec / $\mathrm{Km}^{2}$ of the initial catchment upstream of the MOVO power station).

- Low currents (or low water from May to September):

$1,139 \mathrm{~m} 3 / \mathrm{sec}$ (coming from the aquifer in the near absence of the rains)

- High currents (or high waters) from October to April:

$3.92 \mathrm{~m} 3 / \mathrm{sec}$ (51 liters / sec / $\mathrm{Km}^{2}$ of the initial basin upstream of the MOVO plant).

- The tropical rainfall regime with two main seasons (rainy (7 months), dry (5 months)) has a strong influence on these specific flows, but not under a simple proportionality factor: phenomena such as infiltration, evaporation and evapotranspiration in correlation with the soil and bedrock nature of the granitic-dominated Dibaya Geological system, make this Flow-Rain relationship essentially complex, especially during the transition months (May and September).

\subsection{The Rainfall}

The rainfall of the MOVO watershed to the site of the plant is poorly known due to the lack of rainfall and climatological survey stations located along its course. Through this basin, measures "developed" over relatively long periods, of the order of fifteen years or more, that allow valid statistical classifications do not exist.

This is why the study of the factor "rain" in this project can hardly refer to existing sources:

- The rainfall and climatological station WORLD CLIMAT of KANANGA, nearly $120 \mathrm{~km}$ away from the site of the MOVO plant, by the worldclimate.com website, whose attachment data cover 984 months (1908 to 1990).

- The rainfall station of the TSHIBWE Mine just $12 \mathrm{~km}$ from the site of the Centrale, whose attachment data cover only 25 months (from 2003 to 2005).

The average annual rainfall in Kananga is $1598.7 \mathrm{~mm}$ against $2096.5 \mathrm{~mm}$ in Tshibwe, which confirms the very wet micro-climate of the mine.

On the other hand the small station of the rains that we had implanted at the same time as the measures of the flows: from October 2013 to March 2014 at the current location of the MOVO plant, gives rain records oddly closer to the station of Kananga than that of Tshibwe.

The average annual rainfall in Kananga is $1598.7 \mathrm{~mm}$ against $2096.5 \mathrm{~mm}$ in Tshibwe, which confirms the very wet micro-climate of the mine. Therefore the values from Kananga will prevail to forecast MOVO RIVER MONTHLY FLOWRATE related to monthly height of the rain.

\subsection{Annual Hydrological Reference Regime of MOVO}

Thanks to the surveys from September 2013 to March 2014, and to the help of the rainfall records, each of the 12 months of the year can be referred to the average behavior listed in the following 12 measurement tables. 
Table 2: October 2013 as template of the 12 hydrologic sampling months.

\begin{tabular}{|c|c|c|c|}
\hline Number & $\begin{array}{l}\text { Recording } \\
\text { date }\end{array}$ & Flowrate(m3/s) & $\begin{array}{l}\text { Rainfall height } \\
(\mathrm{mm})\end{array}$ \\
\hline 1 & $01 / 10 / 2013$ & 1,71 & $* * * *$ \\
\hline 2 & $02 / 10 / 2013$ & 1,89 & $* * *$ \\
\hline 3 & $03 / 10 / 2013$ & 1,49 & $* * *$ \\
\hline 4 & $04 / 10 / 2013$ & 1,44 & $* * *$ \\
\hline 5 & $05 / 10 / 2013$ & 1,58 & $* * *$ \\
\hline 6 & $06 / 10 / 2013$ & 1,72 & $* * *$ \\
\hline 7 & $07 / 10 / 2013$ & 2,88 & 0 \\
\hline 8 & $08 / 10 / 2013$ & 2,09 & 0 \\
\hline 9 & 09/10/2013 & 7,69 & 60,39 \\
\hline 10 & $10 / 10 / 2013$ & 11 & 45,69 \\
\hline 11 & $11 / 10 / 2013$ & 3,57 & 0 \\
\hline 12 & $12 / 10 / 2013$ & 3,39 & 15,18 \\
\hline 13 & $13 / 10 / 2013$ & 2,57 & 0 \\
\hline 14 & $14 / 10 / 2013$ & 2,06 & 0 \\
\hline 15 & $15 / 10 / 2013$ & 2,05 & 19,23 \\
\hline 16 & $16 / 10 / 2013$ & 1,92 & 0 \\
\hline 17 & $17 / 10 / 2013$ & 1,81 & 0 \\
\hline 18 & $18 / 10 / 2013$ & 2,56 & 0 \\
\hline 19 & $19 / 10 / 2013$ & 2,61 & 0 \\
\hline 20 & $20 / 10 / 2013$ & 2,54 & 0 \\
\hline 21 & $21 / 10 / 2013$ & 3,31 & 0 \\
\hline 22 & $22 / 10 / 2013$ & 4,35 & 0 \\
\hline 23 & $23 / 10 / 2013$ & 2,23 & 0 \\
\hline 24 & $24 / 10 / 2013$ & 1,6 & 0 \\
\hline 25 & $25 / 10 / 2013$ & 1,45 & 11,24 \\
\hline 26 & $26 / 10 / 2013$ & 1,67 & 7,39 \\
\hline 27 & $27 / 10 / 2013$ & 2,46 & 0 \\
\hline 28 & $28 / 10 / 2013$ & 1,61 & 0 \\
\hline 29 & $29 / 10 / 2013$ & 1,59 & 0 \\
\hline 30 & $30 / 10 / 2013$ & 1,59 & 0 \\
\hline 31 & $31 / 10 / 2013$ & 1,59 & 0 \\
\hline
\end{tabular}

\begin{tabular}{|l|r|}
\hline $\begin{array}{l}\text { Number of day of the } \\
\text { month }\end{array}$ & 31 \\
\hline $\begin{array}{l}\text { Number of day of } \\
\text { sampling }\end{array}$ & 31 \\
\hline Percentage of cover & $100 \%$ \\
\hline Maximum flowrate & $11 \mathrm{~m} 3 / \mathrm{s}$ \\
\hline Minimum flowrate & $1,44 \mathrm{~m} 3 / \mathrm{s}$ \\
\hline Average flowrate & $2,65 \mathrm{~m} 3 / \mathrm{s}$ \\
\hline
\end{tabular}

Hydrometric and rainfall activity report achieved on MOVO river from september $1^{\text {st }} 2013$, to August 31 th 2014

From these tables, it will therefore be possible to describe daily in other tables, the flows usable by the MOVO plant in its current configuration and the configuration of hydraulic structures described above and to deduce consequently the KW and KWH which will be the subject of the latest tables.

N.B.: The low flow of the right tributary of the MOVO, estimated at $0.5 \mathrm{~m} 3 / \mathrm{s}$ was retained following the work done on the Nyingindi which has a basin and a very similar hydrological regime. 


\section{Organization of Civil Engineering Work}

PLANS $\mathrm{N}^{\circ} 18$ to 22 obtained by the software CIVIL 3D and section C.1.3. describe in detail the civil works to be carried out to set up the new configuration.

\section{Economy of the Project Increasing the Energy Deliverable by the Central Movo}

As indicated in C.2.4., The 12 monthly tables represent the one-year picture of MOVO's hydrological regime, whereas it would take 15 years of surveys to meet statistical requirements. However, a large number of physical factors of its basin argue for the regularity of the annual hydrological regime of the MOVO:

- The very small extent of its basin and the regularity of the tropical regime of the rains on this basin.

- The anthropological factors (for example, the rapid evolution of the wooded or cultivated surfaces) do not seem likely to evolve strongly on this basin in the near future or even in the medium term and consequently one should not fear hydrological changes coming from of this factor.

In these conditions of 12 monthly tables of the MOVO hydrological regime, we can draw the monthly tables of the comparison of the operation of the MOVO plant in its present configuration with its 2 basins (initial, and of the accumulation dam); and in its planned configuration with the addition of a new storage tank of $34451486 \mathrm{~m} 3$ and a new catchment area of $14 \mathrm{Km}^{2}$. 
Table 3: October 2013 as template of the 12 months forecast of increased energy availability of planned configuration with the addition of a new storage tank of $34451486 \mathrm{~m} 3$ and a new catchment area of $14 \mathrm{~km}^{2}$.

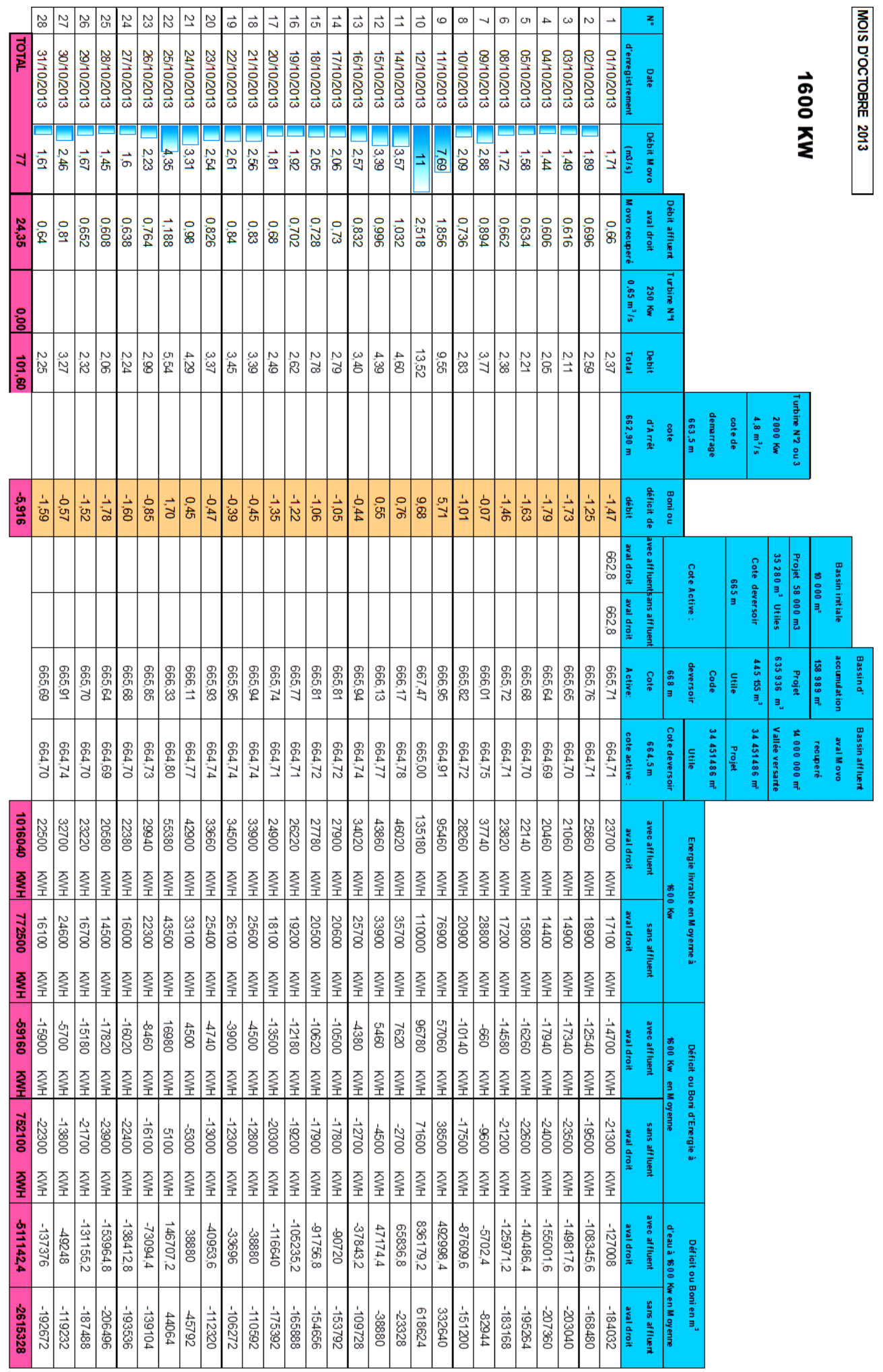


Excel table columns:

1. Number of sampling

2. Dates

3. Movo river Flow $\left(\mathrm{m}^{3} / \mathrm{s}\right)$

4. Flow of Movo tributary sinking inside the storage tank: $0,5+($ MOVO flow $-0,91) * 0,2$

5. Small MOVO Turbine 1 (250KW), rated Flow: $0,65 \mathrm{~m}^{3} / \mathrm{s}$

6. Available total Flow (Movo river + recovered tributary)

7. Big MOVO Turbines 2 et $3\left(2000 \mathrm{KW}\right.$ each), rated Flow $=4,8 \mathrm{~m}^{3} / \mathrm{s}$, starting height at the basin spillway $663,5 \mathrm{~m}$; stopping height $662,9 \mathrm{~m}$. 8. Bonus or deficit of water flow: Available total flow $-3,84 \mathrm{~m}^{3} / \mathrm{s}$

9. Active height at the power plant initial basin: (MOVO Flow/2,83) ${ }^{0,666}+664,5$ (spillways formula in bibliography ref.6)

10. Active height at the extended power plant basin: (Flow from recovered MOVO tributary/7,088) ${ }^{0,666}+664,5 \mathrm{~m}$ (Spillways Formula in bibliography ref.6)

11. Active height (spillway formula) at the power plant basin with the contribution the addition of a new storage tank of $34451487 \mathrm{~m}^{3}$ and a new catchment area of $14 \mathrm{Km}^{2}$ : (Available total Flow/2,83) ${ }^{0,666}+664,5 \mathrm{~m}$ (Spillways Formula in bibliography ref.6)

12.1. Recoverable energy with recovered MOVO tributary: (Available total Flow/4,8) $2000 * 24$

12.2. Recoverable energy without recovered MOVO Tributary: (MOVO Flow/4,8*2000*24

13.1. Bonus or deficit of energy with MOVO tributary: Recoverable energy with recovered MOVO tributary - 38400

13.2. Bonus or deficit of energy without MOVO tributary: Recoverable energy without recovered MOVO Tributary -38 400

14.1. Bonus or deficit of water quantity with MOVO tributary: Bonus or deficit of water flow *3600*24

14.2. Bonus or deficit of water quantity without MOVO tributary: (MOVO Flow $-3,84$ )*3600*24

The comparison for each of 12 months of the year is made at:

A constant power demanded by the Tshibwe Mine of $1600 \mathrm{KW}$ corresponding to the power that it currently requires to produce 250000 carats monthly which is its first objective indicated in its development plan before the last objective which is that of producing 500000 carats / month.

Table 4: Monthly Bonus or Deficit of Water in MOVO in $\mathrm{m}^{3}$ for Constant power demanded by the Tshibwe Mine of $1600 \mathrm{KW}$.

\begin{tabular}{|c|c|c|}
\hline Designation & With additional landscaping & Without further development \\
\hline May & -6286637 & -7662816 \\
\hline June & -6298560 & -7587176 \\
\hline July & -6508512 & -7847712 \\
\hline August & -6008774 & -7431264 \\
\hline September & -3675456 & -5252256 \\
\hline Bonus or Deficit Low - Water & -28777939 & -35781224 \\
\hline October & -511142 & -2615328 \\
\hline November & +1551053 & 1053216 \\
\hline December & -864173 & -3144096 \\
\hline January & +3257107 & $\begin{array}{r}+290304 \\
\text { Non stockable }\end{array}$ \\
\hline February & +4055962 & $\begin{array}{r}+1190592 \\
\text { Non stockable }\end{array}$ \\
\hline March & +7871904 & $\begin{array}{r}+4135968 \\
\text { Non stockable }\end{array}$ \\
\hline April & +6358694 & $\begin{array}{r}+2953152 \\
\text { Non stockable }\end{array}$ \\
\hline Bonus or Deficit High - Water & $\begin{array}{l}\qquad+21719405 \\
\text { STOCKABLE IN THE } \\
\text { AMENAGEMENT }\end{array}$ & $\begin{array}{l}+1757376 \\
\text { N.B. : LOST WITHOUT STORAGE CAPACITY }\end{array}$ \\
\hline Annual Bonus or Deficit & $-\quad 7038534$ & -42593864 \\
\hline
\end{tabular}


- With the planned Development, we should buy more than: $7058534 \times \frac{1}{8,64} \times \frac{1}{3}=272320$ Liters of diesel per year for the Tshibwe plant in production at $250,000 \mathrm{cts} /$ month.

N.B. : Quantity that can be increased by $4 \%$ to account for evaporative water losses.

- Without the planned Development, we will have to buy: $42593864 \times \frac{1}{8,64} \times \frac{1}{3}=1643281$ Liters of diesel / year for the Tshibwe plant in production at $250000 \mathrm{cts} / \mathrm{month}$.

\section{Conclusion}

The differential:

$1,643,281-272,320=1,370,961$ liters of diesel per year, even at 1.2 USD / Liter, on the site of Tshibwe, largely pays the invoice of 357,210 USD necessary for the implementation of the development of the hydraulic works, and will continue to save TSHIBWE MINE annually the invoice of 1370961 liters of diesel oil or 1645153 USD per year to continue its first stage of production of 250000 carats / month.

Therefore it's proven that OPTIMIZING HYDROPOWER PLANT IMPLEMENTATION WITHOUT MORE THAN ONE YEAR BACK HYDROLOGIC DATA is feasible with modern computer software and GPS applications.

\section{References}

[1] R. Bettes, "Aménagement hydroélectrique de la LUFIRA A chutes CORNET(MWADINGUSHA) par régulation de la rivière," Bruxelles, 1941.

[2] Y. L'hote, G. Mahe, "Map of annual average rains in western and central Africa over the period 1951-1989 on the scale of the 1/6000000," ORSTOM ed., 1995.

[3] J. Devroey, “Annuaire hydrologique du Congo-belge et du Rwanda-Urundi,” Bruxelles, 1954-1959.

[4] United Nations, World metrological organization: Guide to undertake hydrometric surveys. 2005.

[5] Notice sur les déversoirs; Traité d'hydraulique à surface libre, Ministère de transports, de l'équipement, tourisme et de la mer, République Française.

[6] World Climate. [Online]. Available: worldclimate.com 